\title{
PENELITIAN
}

\section{FAKTOR YANG MEMPENGARUHI KEBUTUHAN TIDUR PADA PASIEN DENGAN PERUBAHAN FUNGSI PERNAFASAN DI BADAN PELAYANAN KESEHATAN RSU Dr. ZAINOEL ABIDIN BANDA ACEH}

\begin{abstract}
Munardi *
Abstrak

Penelitian fenomenologi ini mempelajari tentang faktor-faktor yang mempengaruhi kebutuhan tidur meliputi aspek fisik, psikologis, lingkungan, dan gaya hidup pada pasien yang mengalami perubahan fungsi pernafasan. Desain penelitian adalah deskriptif korelasi. Sampel dipilih berdasarkan purposif sampling sehingga diperoleh jumlah responden 39 orang. Data diukur dengan menggunakan kuesioner penelitian yang telah diuji konstruk dan kesesuaiannya. Analisa data menggunakan Uji Chi Square ( $\left.\mathrm{x}^{2}\right)$ dengan $\mathrm{x} 0,05$ dan df $2\left(x^{2}\right.$ tabel = 5,991) sehingga diperoleh hasil $x^{2}$ hitung 7,839 dan 11,636 masing-masing untuk hubungan nyeri, faktor psikologis, dan faktor lingkungan terhadap gangguan kebutuhan tidur. Kesimpulan terdapat hubungan yang bermakna antara faktorfaktor yang mempengaruhi tidur dengan gangguan kebutuhan tidur pada pasien dengan perubahan fungsi pernafasan.
\end{abstract}

Kata kunci: faktor-faktor yang mempengaruhi tidur (nyeri, psikologis dan lingkungan) dan gangguan pemenuhan tidur.

\begin{abstract}
This phenomelogical research studied factors influencing sleep. The factors were physical, psychological, environmental and life style of patients with respiratory function disturbance. The research design was descriptive correlation. The sample was selected based on correlation. The sample was selected based on purposive sampling. The number of responden was 39. A questionnaire was tested for validity and reability prior to collect data. A chi-square test was employed to measure the relationship between pain, psychologic and environmental factors, and need of sleep $\left(\alpha 0,05, d f 2, x^{2}\right.$ table: 5,991). The findings showed significant relationship between factors influencing sleep and disturbance of sleeping needs in patients with respiratory function disturbance (calculated $x^{2}$ 7,839 and 11,636).
\end{abstract}

Key words: factors influencing sleep (espain, psychological and environmental) and problem fulfilling sleep.

\section{LATAR BELAKANG}

Kebutuhan fisiologis sebagai kebutuhan utama meliputi; kebutuhan oksigen atau bernafas, makan dan minum, eliminasi, tidur dan istirahat serta kebutuhan seksualitas (Gaffar, 1999). Tidur sebagai salah satu bagian dari kebutuhan fisiologis merupakan kebutuhan dasar yang dibutuhkan oleh semua manusia untuk dapat berfungsi secara optimal baik yang sehat maupun yang sakit. Namun dalam keadaan sakit, pola tidur seseorang biasanya terganggu, sehingga perawat harus berusaha untuk membantu klien memenuhi kebutuhan tidur tersebut (Prihardjo, 1996)

Tidur merupakan bagian penting dari siklus 24 jam dimana manusia harus berfungsi. Manusia menghabiskan lebih kurang sepertiga waktu hidup untuk tidur. Lama waktu tidur yang dibutuhkan oleh setiap orang sangat bervariasi dan tergantung pada usia. Semakin tua usia seseorang akan sedikit pula waktu tidur yang dibutuhkan. Pada usia dewasa seseorang memerlukan waktu tidur sekitar 7 sampai dengan 8 jam. (Kozier, Blais \& Wilkinson, 1995; Potter \& Perry, 1997; Prihardjo, 1996; WHO 1998).

Tidur penting untuk kesejahteraan fisik dan mental, mencegah kelelahan fisik dan mental. Seseorang yang sedang sakit apabila mengalami kurang tidur dapat memperpanjang waktu pemulihan dari sakit (Hudak \& Gallo, 1997). Bila seseorang tidak mampu memenuhi kebutuhan tidur yang cukup akan mengalami masalah fisik dan mental, diantaranya; perasaan capai, kurang konsentrasi, daya ingat berkurang, kurang mampu 
mengambil keputusan, mudah tersinggung dan tidak relaks, mual, pusing serta meningkatkan risiko kecelakaan (Prihardjo, 1996; WHO, 1998). Individu yang dirawat di Rumah Sakit sering mengalami gangguan pemenuhan tidur, baik yang berupa kesulitan untuk memulai tidur, sering terjaga sewaktu tidur maupun bangun terlalu dini (Black, 1997).

Tidur sebagai kebutuhan dasar manusia sangat dipengaruhi oleh berbagai macam faktor yang berakibat timbulnya gangguan pemenuhan tidur pada seseorang. WHO (1998) mengemukakan ada 4 (empat) faktor yang mempengaruhi tidur, yaitu; faktor fisik, psikologis, gaya hidup, dan lingkungan. Seorang pasien dengan gangguan pernafasan dapat pula mengalami kesulitan untuk tidur. Kesulitan untuk tidur ini dapat disebabkan karena struktur fungsi pernafasan sedang terganggu misalnya penyempitan (konstriksi) pada pasien asma. Pengalaman klinik menunjukkan terdapat interaksi yang berarti antara gangguan fungsi pernafasan dan tidur. Tidur dapat menyebabkan semakin buruknya keadaan fungsi pernafasan dan sebaliknya, perubahan fungsi pernafasan juga akan menimbulkan gangguan pada tidur (Antariksa, 1997 dikutip dari Perhimpunan Dokter Paru Indonesia, 1997). Padahal tidur diperlukan pasien dalam proses penyembuhan penyakitnya.

Mengingat dampak gangguan pemenuhan tidur mempengaruhi pasien, maka faktor yang mempengaruhi kebutuhan tidur pada pasien dengan perubahan fungsi pernafasan ini perlu untuk diteliti. Manfaat dari penelitian ini adalah dengan memahami kebutuhan tidur, faktor yang mempengaruhi tidur dan hubungannya dengan gangguan pemenuhan tidur pada pasien dengan perubahan fungsi pernafasan, maka tim kesehatan dapat menetapkan langkah-langkah penting untuk membantu proses penyembuhan pasien melalui upaya memperbaiki kualitas tidur pasien.

\section{BAHAN DAN CARA KERJA}

Aktifitas tidur seseorang sangat dipengaruhi oleh berbagai faktor, yaitu; keadaan fisik, keadaan psikologis, keadaan lingkungan dan gaya hidup (Kozier, Erb, Blais \& Wilkinson, 1995; WHO, 1998). Secara skematis konsep kerangka kerja dapat dilihat pada skema dibawah ini:
Skema 1.

Kerangka kerja penelitian

Variabel Independen (Bebas) Variabel Dependen (Terikat)

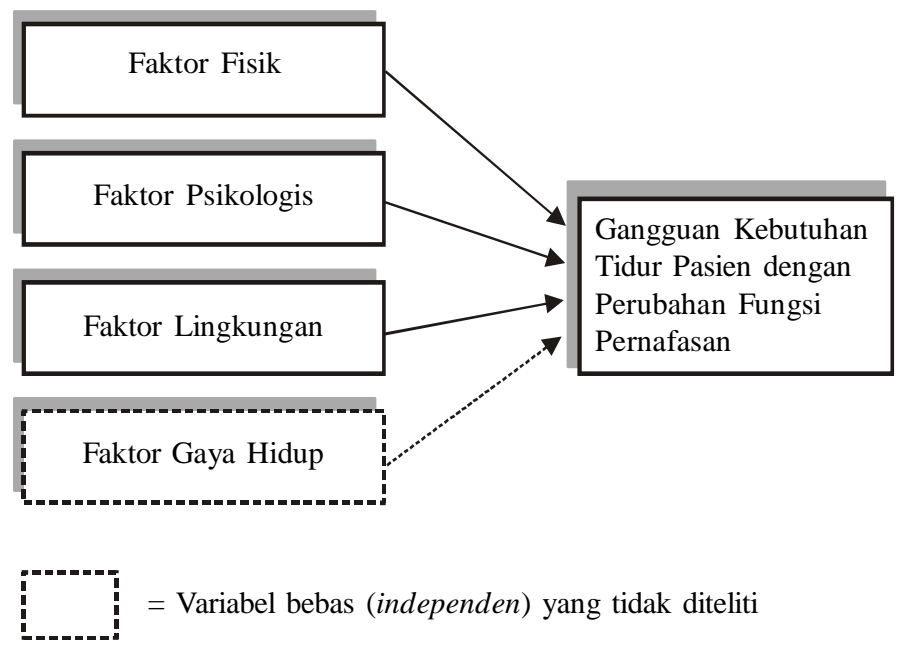

Variabel independen pada penelitian ini meliputi faktor fisik, psikologis, dan lingkungan. Faktor fisik yang dikaji adalah rasa nyeri, sedangkan faktor psikologis yang diteliti terdiri dari depresi, kecemasan, ketakutan, dan tekanan jiwa. Faktor lingkungan meliputi kebisingan, polusi, berkurangnya kebebasan pribadi, dan terlalu ramai. Variabel independen yang diteliti adalah gangguan kebutuhan tidur pasien dengan perubahan fungsi pernafasan. Hipotesis penelitian ini adalah tidak ada hubungan antara faktor yang mempengaruhi tidur dengan gangguan pemenuhan tidur pada pasien dengan perubahan fungsi pernafasan.

Desain Penelitian menggunakan pendekatan deskriptif korelatif untuk memperoleh gambaran tentang hubungan antara faktor-faktor yang mempengaruhi tidur terhadap gangguan pemenuhan tidur pada pasien dengan perubahan fungsi pernafasan. Waktu penelitian Januari-Agustus 2002.

Populasi penelitian adalah pasien yang dirawat di Badan Pelayanan Kesehatan Rumah Sakit Umum Dr. Zainoel Abidin (BPK RSU ZA) Banda Aceh dengan diagnosa keperawatan yang berhubungan dengan perubahan fungsi pernafasan. Sampel yang diteliti berjumlah 39 responden yang dirancang dengan metode purposive sampling.

Kriteria sampel yaitu pasien dengan tingkat kesadaran compos mentis, dirawat lebih dari 1 (satu) hari, lamanya waktu tidur kurang dari 6 jam selama 
siklus 24 jam, dan usia responden dibatasi hanya pada pasien dewasa berusia kisaran 21 tahun sampai dengan 60 tahun.

Pengukuran data terhadap variabel menggunakan kuesioner tertutup (close-ended question), oleh enumerator (mahasiswa PSIK). Kuisioner telah dilakukan uji coba sebelumnya.

Analisis data meliputi pendekatan univarian untuk memperoleh data deskriptif dan bivarian untuk mengukur pengaruh antara faktor fisik, psikologis dan lingkungan terhadap tidur pasien dengan perubahan fungsi pernafasan. Selanjutnya dilakukan analisa silang menggunakan tabel silang (baris x kolom) dengan derajat kebebasan (df) sesuai dengan tingkat kemaknaan 0,05 (95\%) skor diperoleh dengan menggunakan metoda statistic Chi-square test $\left(x^{2}\right)$ Jika setelah dilakukan penggabungan sel sehingga membentuk tabel contigency 2 x 2 namun, masih terdapat nilai frekuensi harapan kurang dari 5, maka dilakukan upaya koreksi dengan menggunakan formula Yate's Correction (Sudjana, 1992).

\section{HASIL}

Hasil pengukuran terhadap variabel gangguan kebutuhan tidur pada pasien dengan perubahan fungsi pernafasan (dalam jam), nilai total adalah 155 , nilai rata-rata $(\bar{X}$ ) adalah 3,974 dan standar deviasi (SD) adalah 0,946. Selanjutnya masingmasing responden dikategorikan berdasarkan kriteria: gangguan kebutuhan tidur ringan apabila nilai $(X) \geqslant$ 4,92, sedang 3,028 $<(X)<4,92$ dan berat $(X)<3,028$. Hasil kategori tersebut terlihat pada tabel 1 .

Tabel 1

Proporsi Responden Berdasarkan Katagori Gangguan Pemenuhan Tidur Di Ruang Rawat Inap BPK RSUZA Banda Aceh Tahun 2002

\begin{tabular}{llcc}
\hline NO & KATEGORI & $\begin{array}{c}\text { FREKUENSI } \\
(\mathbf{f})\end{array}$ & $\begin{array}{c}\text { PROSENTASE } \\
(\boldsymbol{\%})\end{array}$ \\
\hline 1. & Ringan & 13 & 33,33 \\
2. & Sedang & 8 & 20,51 \\
3. & Berat & 18 & 46,16 \\
\hline & Jumlah & 39 & 100 \\
\hline
\end{tabular}

Berdasarkan tabel 1 maka distribusi terbesar kategori gangguan kebutuhan tidur pada pasien adalah gangguan kebutuhan tidur berat $(46,16 \%)$ yaitu waktu tidur < 3,028 jam selama siklus 24 jam. Pengukuran selanjutnya dilakukan terhadap faktorfaktor yang mempengaruhi tidur dengan indikator :

1. Nyeri: Nyeri ringan $(X)<12,11$, sedang 12,11 $\leqslant(X)<24,87$ dan berat $(X) \geqslant 24,87$,

2. Gangguan psikologis: gangguan psikologis ringan $(X)<9,06$, sedang $9,06 \leqslant(X)<15,96$ dan berat $(X) \geqslant 15,96$.

3. Gangguan lingkungan: gangguan lingkungan ringan $(X)<9,25$, sedang $9,25 \leqslant(X)<16,85$ dan berat $(X) \geq 16,85$.

Berdasarkan indikator tersebut maka hasilnya dapat dilihat pada tabel 2 .

Tabel 2

Proporsi Responden Berdasarkan Kategori Nyeri, Gangguan Psikologis dan Gangguan Lingkungan Di Ruang Rawat Inap

BPK RS. UZA Banda Aceh Tahun 2002

\begin{tabular}{rccccccc}
\hline & \multicolumn{2}{c}{ Nyeri } & \multicolumn{2}{c}{ Gangguan Psikologis } & Gangguan Lingkungan \\
\hline \multirow{2}{*}{ Ringan } & $\mathrm{f}$ & $\%$ & $\mathrm{f}$ & $\%$ & $\mathrm{f}$ & $\%$ \\
\cline { 2 - 7 } Sedang & 14 & 35,9 & 12 & 30,8 & 11 & 28,2 \\
Berat & 10 & 25,6 & 14 & 35,9 & 13 & 33,3 \\
& 15 & 38,5 & 13 & 33,3 & 15 & 38,5 \\
\hline
\end{tabular}

Tabel 2 menunjukkan faktor-faktor yang mempengaruhi tidur pada pasien dengan perubahan fungsi pernafasan adalah nyeri berat $(38,5 \%)$ dengan nilai nyeri $(X) \geq 24,87$. Gangguan psikologis tingkat sedang menempati prosentase tertinggi $(35,9 \%)$ dengan nilai $9,06 \leqslant(X)<15,96$. Selain itu, gangguan lingkungan tingkat berat menunjukkan prosentase tertinggi $(38,5 \%)$ dengan nilai (X) $\geqslant 16,85$.

Proporsi kategori gangguan pemenuhan tidur menurut kategori tingkat nyeri, gangguan psikologis dan gangguan lingkungan pada pasien dengan perubahan fungsi pernafasan seperti tergambar pada tabel 3 . 
Tabel 3

Proporsi Kategori Gangguan Pemenuhan Tidur berdasarkan Kategori Tingkat Nyeri, Gangguan psikologis dan Gangguan Lingkungan pada Pasien Dengan Perubahan Fungsi Pernafasan

Di Ruang Rawat Inap BPK RSUZABanda Aceh Tahun 2002

\begin{tabular}{|c|c|c|c|c|c|c|c|c|c|}
\hline \multirow{3}{*}{ Kategori } & \multirow{3}{*}{ Tingkat } & \multicolumn{6}{|c|}{ Gangguan pemenuhan tidur } & & \\
\hline & & \multicolumn{2}{|c|}{ Ringan } & \multicolumn{2}{|c|}{ Sedang } & \multicolumn{2}{|c|}{ Berat } & \multicolumn{2}{|c|}{ Jumlah } \\
\hline & & $\mathrm{f}$ & $\%$ & $\mathrm{f}$ & $\%$ & $\mathrm{f}$ & $\%$ & $\mathrm{f}$ & $\%$ \\
\hline \multirow{4}{*}{$\begin{array}{l}\text { Tingkat } \\
\text { Nyeri }\end{array}$} & Ringan & 6 & 15,38 & 3 & 7,69 & 5 & 12,82 & 14 & 35,89 \\
\hline & Sedang & 5 & 12,82 & 3 & 7,69 & 2 & 5,13 & 10 & 25,64 \\
\hline & Berat & 2 & 5,13 & 2 & 5,13 & 11 & 28,20 & 15 & 28,20 \\
\hline & Jumlah & 13 & 33,34 & 8 & 20,51 & 18 & 46,15 & 39 & 100 \\
\hline \multirow{4}{*}{$\begin{array}{l}\text { Gangguan } \\
\text { Psikologis }\end{array}$} & Ringan & 7 & 17,95 & 2 & 5,13 & 3 & 7,69 & 12 & 30,72 \\
\hline & Sedang & 4 & 10,26 & 5 & 12,82 & 5 & 12,82 & 14 & 35,9 \\
\hline & Berat & 2 & 5,13 & 1 & 2,56 & 10 & 25,64 & 13 & 33,33 \\
\hline & Jumlah & 13 & 33,34 & 8 & 20,51 & 18 & 46,15 & 39 & 100 \\
\hline \multirow{4}{*}{$\begin{array}{l}\text { Gangguan } \\
\text { Lingkungan }\end{array}$} & Ringan & 7 & 17,95 & 2 & 5,13 & 2 & 5,13 & 11 & 28,21 \\
\hline & Sedang & 5 & 12,82 & 4 & 10,26 & 4 & 10,26 & 13 & 33,34 \\
\hline & Berat & 1 & 2,56 & 2 & 5,13 & 12 & 30,77 & 15 & 38,46 \\
\hline & Jumlah & $\mathrm{f}$ & 33,34 & 8 & 20,51 & 18 & 46,15 & 39 & 100 \\
\hline
\end{tabular}

Tabel3 menunjukkanbahwa 18 responden $(46,15 \%)$ berada pada kategori gangguan pemenuhan tidur berat. Jumlah ini berasal dari data gangguan tidur yang berkategori berat yang terdiridari 11 responden $(28,20 \%)$ mengalami nyeri berat, 10 responden $(25,64 \%)$ mengalami gangguan psikologis berat dan 12 responden (30,77\%) mengalami gangguan lingkungan berat. Dengan demikian dapat disimpulkan bahwa semakin ringan gangguan yang dirasakan semakin ringan pula gangguan pemenuhan tidur yang dialami responden. Sebaliknya semakin berat gangguan yang dirasakan semakin berat pula gangguan pemenuhan tidur responden

Hasil analisa selanjutnya melihat hubungan antara faktor nyeri dan gangguan permasalahan tidur diperoleh nilai $x^{2}$ hitung 7,839, dan tabel $x^{2}$ 5,991. Perbandingan antara kedua nilai $x^{2}$ tersebut diperoleh hasil bahwa $x^{2}$ hitung $(7,839)>x^{2}$ tabel $(5,991)$. Hal ini menunjukkan hipotesa kerja (H0) ditolak yang berarti ada hubungan yang bermakna antara nyeri dengan gangguan pemenuhan tidur pada pasien dengan perubahan fungsi pernafasan.

Hubungan antara faktor psikologis dengan kebutuhan tidur pada pasien dengan perubahan fungsi pernafasan, yaitu diperoleh nilai $x^{2}$ hitung adalah 7,726. Selanjutnya dilakukan pengujian hipotesa dimana $x^{2}$ tabel dengan $\alpha=0,05$ dan $\mathrm{df}=2$ adalah 5,991. Perbandingan antara kedua nilai $x^{2}$ tersebut diperoleh hasil bahwa $x^{2}$ hitung $(7,726)>x^{2}$ tabel $(5,991)$. Hal ini menunjukkan hipotesa kerja (H0) ditolak yang berarti ada hubungan yang bermakna antara keadaan psikologis dengan kebutuhan tidur pasien dengan perubahan fungsi pernafasan.

Hubungan antara keadaan lingkungan dengan gangguan kebutuhan tidur pasien dengan perubahan fungsi pernafasan, berdasarkan perhitungan di atas, maka diperoleh nilai $x^{2}$ hitung adalah 11,636. Selanjutnya dilakukan pengujian hipotesa dimana $x^{2}$ tabel dengan $\alpha=0,05$ dan $\mathrm{df}=2$ adalah 5,991. Perbandingan antara kedua nilai $x^{2}$ tersebut diperoleh hasil bahwa $x^{2}$ hitung $(11,636)>x^{2}$ tabel $(5,991)$. Hal ini menunjukkan bahwa hipotesa kerja (H0) ditolak yang berarti ada hubungan yang bermakna antara keadaan lingkungan dengan gangguan pemenuhan tidur pada pasien dengan perubahan fungsi pernafasan. 


\section{PEMBAHASAN}

Tidur merupakan kebutuhan dasar yang dibutuhkan setiap manusia, namun dalam keadaan sakit, pola tidur biasanya terganggu yang disebabkan oleh berbagai faktor. WHO (1998) mengemukakan ada 4 (empat) faktor yang mempengaruhi tidur, yaitu: faktor psikologis, faktor fisik (nyeri), faktor lingkungan dan faktor gaya hidup (tidak diteliti).

Berdasarkan hasil penelitian kepada pasien dengan diagnosa keperawatan perubahan fungsi pernafasan sebagai responden di BPK RSUZA Banda Aceh diperoleh data bahwa 39 responden yang terlibat pada penelitian ini mengalami gangguan pemenuhan kebutuhan disebabkan faktor di atas. Dari 39 responden gangguan pemenuhan tidur didapatkan kategori gangguan pemenuhan tidur terbanyak adalah gangguan pemenuhan tidur berat yaitu sebanyak 18 orang atau 46,16\%. Sedangkan kategori gangguan pemenuhan tidur ringan sebanyak 13 orang atau $33,33 \%$, dan gangguan pemenuhan tidur sedang sebanyak 8 orang atau $20,51 \%$. Hal ini sesuai dengan dasar teori yang dikemukakan oleh Antariksa (1997) yang dikutip dari Perhimpunan Dokter Paru Indonesia (1997), yang mengemukakan terdapat interaksi yang berarti antara perubahan fungsi pernafasan dan tidur. Gangguan kebutuhan tidur dapat menyebabkan semakin buruknya gangguan fungsi pernafasan, dan sebaliknya perubahan fungsi pernafasan juga menimbulkan gangguan pada tidur. Jumlah responden dengan kategori gangguan pemenuhan tidur ringan lebih besar dari responden dengan kategori gangguan pemenuhan tidur sedang. Hal ini mungkin saja terjadi karena dipengaruhi oleh penggunaan obat-obatan yang mempunyai efek penenang dan pengaruh dari faktor-faktor lain yang tidak diteliti dalam penelitian ini.

Berdasarkan data yang didapatkan pada saat penelitian, diperoleh gambaran bahwa ada hubungan yang bermakna antara nyeri dengan gangguan pemenuhan tidur pasien dengan perubahan fungsi pernafasan. Hal ini sesuai dengan dasar teori dimana nyeri sebagai suatu rangsang rasa sakit yang tidak menyenangkan merupakan salah satu faktor yang sangat sensitif dan memberikan pengaruh besar terhadap gangguan tidur seseorang yang dirawat di rumah sakit yaitu merasa sulit untuk tidur, tidak dapat tidur dengan tenang, dan sering terbangun dari tidur (Black, 1997; Miller, 1995).

Gambaran kategori gangguan psikologis yang dirasakan responden, setelah dianalisis menunjukkan bahwa ada hubungan yang bermakna antara keadaan psikologis dengan gangguan kebutuhan tidur pada pasien dengan perubahan fungsi pernafasan Hal ini sesuai dengan dasar teori yang dikemukakan oleh WHO (1998), yaitu kualitas dan kuantitas tidur sangat dipengaruhi oleh keadaan psikologis yang dialami seseorang meliputi: kecemasan, ketakutan, depresi, dan tekanan emosional (stress). Ketakutan dan kecemasan akan menyebabkan seseorang sulit untuk tidur dan sering terbangun dari tidur. Sedangkan pada depresi disamping sulit untuk memasuki tidur, juga menyebabkan bangun terlalu awal dan tidak dapat tidur lagi setelah bangun. (Black, 1997; Miller, 1995; Potter \& Perry, 1997).

Gambaran kategori gangguan lingkungan yang dirasakan responden setelah dianalisis menunjukkan ada hubungan yang bermakna antara keadaan lingkungan dengan gangguan kebutuhan tidur pada pasien dengan perubahan fungsi pernafasan. Hal ini sesuai dengan dasar teori yang dikemukakan oleh WHO (1998), yaitu bising, polusi, berkurangnya area pribadi, dan ruang tidur yang terlalu ramai dapat menyebabkan seseorang sulit untuk tidur dan sering terbangun dari tidur.

Dari uraian di atas dapat disimpulkan bahwa semua faktor yang mempengaruhi tidur yang diteliti (nyeri, keadaan psikologis dan keadaan lingkungan) menunjukkan adanya hubungan yang bermakna dengan gangguan pemenuhan tidur pada pasien perubahan fungsi pernafasan yang dirawat di Ruang Rawat Inap BPK RSU dr. Zainoel Abidin Banda Aceh. 


\section{KESIMPULAN}

Penelitian ini didapatkan bahwa terdapat hubungan yang bermakna antara nyeri dengan gangguan kebutuhan tidur pada pasien dengan perubahan fungsi pernafasan. Semakin ringan tingkat nyeri yang dirasakan maka cenderung semakin ringan pula gangguan pemenuhan tidur demikian pula sebaliknya. Keadaan psikologis juga berhubungan dengan gangguan kebutuhan tidur pada pasien dengan perubahan fungsi pernafasan. Semakin ringan gangguan psikologis yang dirasakan maka cenderung semakin ringan pula gangguan pemenuhan tidur demikian pula sebaliknya. Keadaan lingkungan berhubungan juga dengan gangguan kebutuhan tidur pada pasien dengan perubahan fungsi pernafasan. Semakin ringan gangguan lingkungan yang dirasakan maka cenderung semakin ringan pula gangguan pemenuhan tidur demikian pula sebaliknya.

Penelitian ini menyarankan perlunya mengkaji faktor-faktor yang mempengaruhi kebutuhan tidur sehingga mampu menetapkan intervensi asuhan keperawatan guna mengatasi masalah tidur pasien. Penelitian selanjutnya perlu melihat pengaruh gaya hidup terhadap gangguan pemenuhan kebutuhan tidur pada pasien dengan perubahan fungsi pernafasan. Kepada pengambil kebijakan di pelayanan rumah sakit untuk dapat memprioritaskan penataan ruang rawat inap yang bersih, nyaman dan memperketat jadwal kunjungan tamu sehingga pasien yang dirawat dapat beristirahat dan tidur dengan tenang (ENT).

* Munardi, SKp., M.NSc. : Staf Pengajar Bagian Medikal Bedah PSIK-FK Universitas Syiah Kuala Banda Aceh.

\section{KEPUSTAKAAN}

Black J. M. (1997). Medical surgical nursing. ( $5^{\text {th }}$ edition.) Philadelphia: Esther Matassarin-jacobs Wb. Saunders Company.

Gaffar L. O. J. (1999). Pengantar perawatan profesional, edisi 1. Jakarta: EGC.

Hudak C. M. \& Gallo B.M. (1997). Keperawatan kritis. (edisi 6), Jakarta: EGC.

Kozier; Blais \& Wilkinson (1995). Fundamentals of nursing. ( $2^{\text {nd }}$ edition). California: Addition-Whesley Publishing Company.

Miller C. A. (1995). Nursing care of older adults. ( $2^{\text {nd }}$ edition). Philadelphia: J. B. Lippincoot Company.

Perhimpunan Dokter Paru Indonesia (1997). Jurnal Respirologi Indonesia, Volume 17, Jakarta.

Potter P. A \& Perry A. G (1997). Fundamental of nursing. ( $4^{\text {th }}$ edition). London: Mosby-Year Book, Inc.

Prihardjo R. (1996). Perawatan nyeri: Pemenuhan aktifitas istirahat pasien. Jakarta: EGC

Smeltzer S. C. Bare B.G. (1995). Textbook of medicalsurgical nursing. ( $8^{\text {th }}$ edition). Philadelphia: J. B. Lippincott Company.

Sudjana (1992). Metoda statistika. (Edisi V) Bandung: Tarsito.

WHO. (1998). Mental disorder in primary care: Sleep problem, devision of mental health and prevention of substance abuse. WHO, CH-1221 Geneva 27 Switzerland. 